\title{
Human Resource Information System: A Review of Previous Studies
}

\author{
Nishad Nawaz Maditheti (Corresponding Author) \\ Assistant Professor \\ College of Business Administration, Kingdom University, P.O. Box 40434, Bahrain \\ E-mail: n.navaz@ku.edu.edu \\ Anjali Mary Gomes \\ Assistant Professor \\ College of Business Administration, Kingdom University, P.O. Box 40434, Bahrain \\ E-mail: a.gomes@ku.edu.edu
}

\author{
Received: April 12, $2017 \quad$ Accepted: June 4, $2017 \quad$ Published: July 1, 2017 \\ doi:10.5296/jmr.v9i3.11488 \\ URL: https://doi.org/10.5296/jmr.v9i3.11488
}

\begin{abstract}
This paper aims to review research on the topic human resource information system to establish the current body of knowledge, in this regard, the researchers suggest some promising avenues for future research and the study consists of a systematic review of 155 referred articles on human resource information system. The findings contribute to a more holistic view of the topic and complement the study of human resource information system. Additionally, a conceptual framework is proposed that aims at guiding and informing future research activities. This study may not enable a complete coverage of all articles in the field of human resource information system. However, based on the selected research methodology, it seems reasonable to assume that the review process covered a large share of studies available. And moreover to the best of author's knowledge, there is no systematic review on human resource information systems previously published in academic journals.
\end{abstract}

Keywords: human resource information systems, HR acquire, HR develop, HR pay, HR retain, HR interact, systemic literature review. 


\section{Introduction}

This article review research on human resource information system to establish the current body of knowledge and to suggest some avenues for further research activities. Human resource information system is mainly connected with information technology for rendering services to the human resource management.

In the era of information, communication \& technology, organization management has been changed in the present scenario known as the "digital era" Most of the human resource functions have rapidly been changing by involving information technologies, (Hendrickson, 2003), (McCrindle, 2006), (Nishad Nawaz Maditheti, 2017), HR has new phase of HR processes and practices such as, e-recruitment, e-performance, e-learning, e-selection and other areas to replace the more traditional ones(Gueutal, H.G. and Stone, 2005), (Nishad Nawaz and Anjali, 2012). The present period concepts like virtual or electronic HRM denote the latest phase of usage of HRIS.

A large number of the institutions are leaving the tradition personnel management function and moving towards modern approaches of human resource information systems (Brien, 2008). The knowledge economy focusing the organization to go with digital human resource,(Nishad Nawaz Maditheti, 2017), the human resource management issues are concern for all levels of the line-mangers, because they have reached their goals in-time, which required effective and efficient manpower (Dessler Gary, Cole Nina D., 2008), in meanwhile (K. S. Ball, 2001), (Schuler R.S., Jackson S.E., 2001), (Ostermann, H., Staudinger, B.,\& Staudinger, 2009) and (Mayfield M., Mayfield J., 2003) noted that one such major changes is embedding of information technology in support of the HRM process. Additionally, as per (Ulrich D, 1997) having human resource information systems facilitate and improves human resource professionals own standing in the competitive field. Another piece of work(Nishad Nawaz, 2013b) having human resource information system increase the human resource process effectively with the human resource department.

Since decades, there has been an increased recognition of the need to incorporate a wider range of information on personnel in order to ensure an effective HRM decision-making process (Tetz, 1974), (Nishad Nawaz, 2014). Human resource information system acting on more sophisticated information expert systems mainly support decision-making in managing human skills (Ostermann, H., Staudinger, B.,\& Staudinger, 2009), (Nishad Nawaz, 2014). The use of human resource information system would allow for the human resource function to become more efficient and facilitate better information for decision making (Beadles, Lowery, Johns, Aston, \& Ii, 2005), (Nishad Nawaz, 2014).

Usage of Information Technology has increased the effectiveness and efficiency of all tenets like planning, recruitment process. human resource accounting, training and development and other process of human resource management (HRM). Similarly, with the passage of time, human resource information system (HRIS) has become an inseparable part of modern organizations (Kapoor, 2012), (Nishad Nawaz, 2013b), (Nishad Nawaz and Anjali, 2012).

The human resource information system facilitates the human resource department with 
greater information processing, enhance the communication and reduce the human resource cost (Awazu, Y., \& Desouza, 2003), (Nishad Nawaz, 2012a), (Nishad Nawaz, 2012c).

The computer based information technology serves heavily to the human resource information system applications, which provide rapid information dissemination and feedback would be impossible by not having computerized support, (Benjamin, Alan, and Benson, 1986), (Nishad Nawaz and Anjali, 2014), (Nishad Nawaz, 2014), (Nishad Nawaz, 2012a), (Nishad Nawaz, 2013b), (Nishad Nawaz, 2012c), and (Nishad Nawaz Maditheti, 2017). Based on a systematic review, this paper proposes a conceptual framework that can be used to know the human resource information systems' contribution to human resource management services.

\section{Methodology}

The present study embedded with systematic review followed a combined approach of (Levy \& Ellis, 2006) having proposed Three principles for systematic reviews, which are as follows,

(1) Literature Review Input

(2) Literature Review Processing

2. i Mapping the filed through a scoping review,

2.ii Comprehensive search,

2.iii Quality assessment, which comprises the reading and selection of the paper,

2.iv Data extraction, which refer to the collection of relevant data and the capturing of the data into a pre-designed extraction sheet.

2.v Synthesis, which comprises the synthesis of the extracted data to show, known and to provide the basis for establishing the unknown.

(3) Literature Review Output, which comprises the write-up.

The book of (Petticrew \& Roberts, 2006) on SLRs in the social sciences, (A. G. Fink, 2005) guide on SLRs in health sciences; (Rousseau, Manning, \& Denyer, 2008) article on SLRs in management and organization science; (Levy \& Ellis, 2006) article on conducting literature reviews in information systems; and (Webster \& Watson, 2002) article on writing up literature reviews in information systems.

(Chris Hart, 1998) mentioned that literature review as "the use of ideas in the literature to justify the particular approach to the topic, the selection of methods, and demonstration that this research contributes something new" (p. 1) and added a new note to the previous literature review, "quality means appropriate breadth and depth, rigor and consistency, clarity and brevity, and effective analysis and synthesis" (Chris Hart, 1998) ( p. 1). (Sethi \& King, 1998), The paper presents the literature review process in a systematic way following the

"input processing-output" approach. "Process" is defined in the context of this work as 
sequential steps of activities.

Developing a solid foundation for a research study is enabled by a methodological analysis and synthesis of quality literature(Barnes, 2005); (Webster \& Watson, 2002).

(D. Fink, 1998) have proposed the factors into adoption of IT for internal and external environment, with internal IT, get benefits in organizational culture, in-house, IT expertise and resources, IT implementation and selection and external environment service to outside and resources in HRIS.

In the following, we explain how we proceeded.

First, we designed a research plan comprising the research questions. Which we were interested in answering. This also involved the keywords, and a set of inclusion and exclusion criteria. This also involved the keywords, and a set of inclusion and exclusion criteria. As we were interested in establishing the current body of knowledge regarding human resource information system and in identifying promising avenues for future research, we decided to use multiple keywords to identify relevant studies. Such as human resource information system, human resource management systems, E HR, adoption of HRIS, implementation of HRIS and Information Technology Services into HRM. The inclusion criteria were empirical / Theory Development, peer-reviewed, English language and indexed in the database. Google Scholar, Research Gate, Academia, ABI inform, EBSCO, Scopus and Web of knowledge. We excluded gray literature such as reports and non-academic research, and other than English. Additionally, we developed an excel data sheet consisting of criteria relevant for establishing our understanding of human resource information systems.

Second, one of us accessed the four databases and searched using combinations of the keywords set. We looked for combinations of these keywords in the title, keywords and abstract. The literature review included papers published until May, 30, 2017. Depending on the combination of keywords used, different numbers of hits were generated. 2 (ii ) \& (iii) each of us manually scanned the abstract of the respective papers and, if relevant, more parts of the articles to make sure that they actually fell within our scope of interest. This reduced the number of articles without duplications to final number 196 articles, which fulfilled our criteria and were than analyzed. 2 (iv), the papers were divided among the authors. That is, each read 98 papers, respectively, and coded accordingly to the criteria specification in Table 1. (v), in the next stage, the individual data were synthesized into one. Then, each author individually worked through the merged sheet to check for consistency regarding the coding and our different views were shared and discussed during our discussion round. These discussion rounds led to a further reduction of the number of papers. At the end, 155 papers formed the basis for analysis. Third, and the final stage of our review was devoted to the write-up of the findings. 
Table 1. Description of criteria used to analyze research on human resource information system

\begin{tabular}{|c|c|c|}
\hline Criteria & Meaning & Description \\
\hline $\begin{array}{l}\text { Date of } \\
\text { publication }\end{array}$ & $\begin{array}{l}\text { Year of } \\
\text { publication of the } \\
\text { article }\end{array}$ & Stating of year \\
\hline $\begin{array}{l}\text { Author's } \\
\text { nationality }\end{array}$ & $\begin{array}{l}\text { Country where is } \\
\text { located the first } \\
\text { author's institution }\end{array}$ & Stating of country \\
\hline $\begin{array}{l}\text { Research } \\
\text { team }\end{array}$ & $\begin{array}{l}\text { Number of } \\
\text { authors }\end{array}$ & 1. one, 2. two, 3. three and more \\
\hline $\begin{array}{l}\text { Journal } \\
\text { publication }\end{array}$ & Title of the journal & $\begin{array}{l}\text { 1. HRM/2. Business Management/ } 3 \text {. Information System/ } \\
\text { 4. others }\end{array}$ \\
\hline Topic & $\begin{array}{l}\text { Main topic } \\
\text { explored in the } \\
\text { study }\end{array}$ & $\begin{array}{l}\text { 1.decison making, 2. strategic planning, 3. Organizational } \\
\text { performance, 4. Adoption \&usage, barriers, } 5 . \\
\text { Implementation \& assessment, 6. Technology transfer }\end{array}$ \\
\hline Disciplines & $\begin{array}{l}\text { Disciplinary } \\
\text { background of } \\
\text { study }\end{array}$ & $\begin{array}{l}\text { health science, information systems, Financial firms, } \\
\text { Universities }\end{array}$ \\
\hline $\begin{array}{l}\text { Number of } \\
\text { disciplines }\end{array}$ & $\begin{array}{l}\text { Number of } \\
\text { disciplines used in } \\
\text { the same study }\end{array}$ & 1. one, 2. two, 3. three, 4 . four \\
\hline $\begin{array}{l}\text { Theoretical } \\
\text { aim }\end{array}$ & $\begin{array}{l}\text { Nature of the } \\
\text { theoretical aim of } \\
\text { the paper }\end{array}$ & $\begin{array}{l}\text { 1. empirical, 2. theory development, 3. explore, 4. testing } \\
\text { \& implementation, 5. others }\end{array}$ \\
\hline $\begin{array}{l}\text { Research } \\
\text { setting }\end{array}$ & $\begin{array}{l}\text { Contients of the } \\
\text { theoretical setting } \\
\text { of the study }\end{array}$ & $\begin{array}{l}\text { 1.Europe, 2. North America,3. Asia, 4. Australia, 5. Africa, } \\
\text { 6. Arab, 7. Multi }\end{array}$ \\
\hline $\begin{array}{l}\text { Number of } \\
\text { research } \\
\text { settings }\end{array}$ & $\begin{array}{l}\text { Number of } \\
\text { countries of the } \\
\text { theoretical setting }\end{array}$ & 1. national, 2. multi-national \\
\hline $\begin{array}{l}\text { Research of } \\
\text { methods }\end{array}$ & $\begin{array}{l}\text { Instrument of data } \\
\text { collection }\end{array}$ & $\begin{array}{l}\text { 1. Observation, 2. Participation, 3. Interviews, 4. Survey, } 5 . \\
\text { Archival, 6. Experiment, } 7 \text { Others }\end{array}$ \\
\hline $\begin{array}{l}\text { Number of } \\
\text { methods }\end{array}$ & $\begin{array}{l}\text { Number of } \\
\text { different methods } \\
\text { of data collection }\end{array}$ & 1. single source, 2 . multiple source \\
\hline $\begin{array}{ll}\text { Level of } \\
\text { analysis }\end{array}$ & $\begin{array}{l}\text { Level of analysis } \\
\text { of the study }\end{array}$ & $\begin{array}{l}\text { 1. group, 2. Firm, 3.Individual, 4. Organization, } 5 . \\
\text { National, 6. Relational, 7. Multiple }\end{array}$ \\
\hline
\end{tabular}

\subsection{Specific of criteria}

In the following, the intention with each criterion is briefly outlined. 


\subsubsection{Date of publication}

To determine when current body of knowledge of human resource information systems was made available to the research community, we captured the year of publication of every year.

\subsubsection{Country of authors' institutions}

To get the information about the starting point of research on human resource information systems, we have coded the country of the first authors' institution. This type of information would provide insights into where the body of knowledge in the field under investigation has been established. It may also signal certain countries preferences (McNulty, Zattoni, \& Douglas, 2013).

\subsubsection{Size of research team}

The size of the research team helped us in determining whether the existing work is a synthesis of different individuals' knowledge bases or whether it is more of a result of research performed by individual researchers.

\subsubsection{Journal of publication}

To get the data concerning from which field the existing body of knowledge emerged, we classified the journals according to the four broad categories.

(1) Human resource management journals;

(2) Business management journals;

(3) Information systems Journals; and

(4) Others.

\subsubsection{Disciplines}

Human resource information system is a broad topic that has the power to attract scholars from different disciples. Consequently, it would be interesting to know which discipline provides which theoretical framework, as this influences how human resource information system is considered and discussed. These frameworks can be used to probe different research questions in the context of the human resource information systems phenomenon. To approach this factor, we have seen the peer-review process as a mechanism to check the quality (Davison et al., 2005).

\subsubsection{Number of disciplines involved}

To understand and study the complexity of human resource information system, scholars may take advantage of this mechanism to check the quality of the journals.

\subsubsection{Theoretical aim}

To understand the author's orientation towards the study of the human resource information system, we were interested in gaining insights into the paper's theoretical contribution. Consequently, a paper's aim, from the perspective of the topic of human resource information 
system could have been to explore, to develop (elaborate) or to test (validate). This understanding would indicate the maturity of the research field as well as the boundaries of the topics, it is into greater focus on empirical testing that helps to develop consensus on the boundaries of the topic.

\subsubsection{Research setting}

Here, we looked into where research on human resource information system has taken place to understand the extent of influence of organizational context. To do so, we coded for continents, i.e Europe, North America, Arab, Asia, Australia and Africa. We also coded for situations where more than one continent was involved. This also referred to articles that comprised more than one country in continent.

\subsubsection{Number of research settings}

This criterion tried to get more information about the influence of organizational setting on research activities in the area of human resource information system. Are we talking about the organizational setting and /or is there an emphasis on studying human resource information system across the organizations?

\subsubsection{Research methods}

To understand what the existing information of human resource information system is based upon, we examined the instrument used to collect data / theory development / case study. This information also contributes to the determination of any preferred researches (i.e qualitative vs quantitative research).

\subsubsection{Number of research methods}

A combination of research methods does not only help to obtain a more holistic understanding of a topic. It also provides the opportunity of offsetting the weakness of one instrument with strength of another one (Bryman, 2012). Consequently, we coded for "mono-method approach and "mixed-methods approach.

\subsubsection{Level of analysis}

Human resource information system can happen at different levels. Therefore, it is important to find out at which level the researchers tried to capture it. We coded for articles that focused on individual, group level, firm level, national level and relational level of analysis (i.e this refer to studies that take advantage of a number of different levels of analysis, for example firm and individual level.

\subsubsection{Topic}

As the study of human resource information system is a recent one, one would assume that the scope of activity is rather fragmented and mainly driven by individual scholar's and their preferences. Therefore, we decided not to specify any topics in advance but let them emergence from each authors' perception and subsequent joined discussion. 


\section{Results}

\subsection{Date of publication}

Among the 155 papers that formed the basis for our analysis, the oldest publication from 1986 and the most recent one are from 2017. The mass of research gas been conducted in the 2013, $2014 \& 2015$ in particular. This clarifies that this topic is still in its infancy. The short history of the research regarding human resource information system also explains why this area can be assessed as under-researched.

\subsection{Country of authors' institutions}

Our data show that authors from many countries have published articles about human resource information system, which indicates a global interest in the topic. So far, the study of the topics seems to be dominated by authors from the USA, followed by the UK, India, Australia, Jordan, Saudi Arabia, Bahrain and at least Cameron. We also observed many single contributions from individual countries, which suggests that the study of human resource information system is currently driven by individual actors or research groups / institutions.

\subsection{Size of research team}

Regarding the composition of the research team, our results show that 45 articles were produced by a single author. The majority of papers, however, have been the product of at least two researchers (48 papers) or there and more authors (62papers). This indicates that the majority of the existing research is a synthesis of different individuals' knowledge bases, which is not surprising, given the time and resource needed to develop a paper. Additionally, these joint activities provide the opportunity of including different perspectives, which in turn, can increase the likelihood of taking a more holistic approach regarding the study of human resource information system.

\subsection{Journal of publication}

With regard to the journals that have published research on human resource information, one can see a broad mix, i.e journals can be assigned to the areas of human resource management, business management, information systems, as well as the other specializations journals.

The majority of publications were found in the business management area, which stresses the critical importance of managing human resource information.

In the next number step, we also organized our data regarding the topics journal distribution. The largest number of articles has been published in the Journal of Human Resource Management with eight papers. This is followed by the Journal of Personnel Review with four papers, the Human Resources for Health, the International Journal of Business and Management, the American Journal of Industrial and Business Management, the MIS Quarterly, the Indian Journal of Applied Research with three articles, the International of Human Resource Management, the Asia Pacific Journal of Human Resources, the European Journal of Business and Management, the Journal of Management Research, the International Journal of Advanced Research in Engineering \& Management, the International Business 
Research, the International Journal of Academic Research in Business and Social Sciences, the Academy of Management Journal, the Creativity and Innovation Management, the Journal of Quality and Technology Management, the Journal of Information and Knowledge Management Systems, the International Journal of Management, IT and Engineering, the Journal of Strategic Information Systems, the Procedia - Social and Behavioral Sciences, the National Institute for Health Research, the Global Journal for Research Analysis, the Journal of the American Medical Informatics Association, the Australian Journal of Basic and Applied Sciences, the IIM Ahmedabad, the Journal of Business Ethics, the Personnel Psychology with two articles each. All the other papers have been published in other journals. This indicates that the study of human resource information system enriches a number of different research disciplines.

\subsection{Discipline and number of disciplines}

The findings highlight that the study of human resource information system dominated by Business Management (85 articles), followed by Information Systems (32 articles), Human Resource Management (22 articles) and conferences (16 articles). However, with regard to the number of different disciples applied, we found that several authors made use of a number disciplines. For example, the authors used theoretical lenses from the disciplines of management, human resource management and information system.

\subsection{Theoretical aim}

There are different ways to develop theory or to contribute to its further development. Our findings showed that the majority of papers (61 articles) had theory development focus. In addition to that empirical (50 article), awareness raising (25 articles), explore and case study based each 6 articles, normative based 4 articles and testing and implementation 3 articles. This underlines that the topic of human resource information system is still in its infancy, which calls for more testing and implementation to develop the field. It also implies that the study of human resource information system is rather fragmented and influenced by those researchers; personal interest.

\subsection{Research setting and number of research settings}

The majority of studies have been conducted in Asia (47 articles), followed by Europe (41 articles), North America 31 articles, Arab with twenty articles, Australia with ten articles and Africa six paper. The papers covered four times in one continent or several countries in one continent. In sum, our findings clearly indicate that research on human resource information system is driven by the Europe and North America from the rest of the world.

If one has a closer look at the research setting. In regard to the industry level 47 papers, national level 30 papers, employee focused 29 articles; technology focused 44 papers and inter countries five papers.

\subsection{Research methods}

This part will be explaining insights into the instruments used for designing of article related to human resource information systems. The findings demonstrate that there are three 
dominating instruments which are interviewed ( 3 studies used them), 66 articles involved a survey and 75 articles used of theoretical background and the remaining articles that used instruments such as workshops, conferences.

In the matter of research methodology, we found most of the papers were clear and specific of the methodology and rest of the articles done with clear observation is that findings presented should be taken with caution.

\subsection{Number of research methods}

Additionally, we coded for the number of data instruments applied. A total of 44 articles were based on mono method, and 19 articles used mixed method approach. Even though the latter is promising, as it provides more in-depth insights into human resource information systems, it also clarified that there is a potential for mono-methods studies to develop further our understanding of human resource information system and their concepts.

\subsection{Level of analysis}

The study of human resource information systems offers the opportunity to approach it from many different levels of analysis. Our findings show that 47 articles were based on the industry level. This was followed by technology 44 articles, 30 articles national level, 29 articles employee level and rest of the articles inter-country level.

We have noticed that the many of the articles not provided right analysis. Our data also left the impression that a small number of papers addressed the consequences of human resource information system. From our point of view, however, it would be a promising perspective to get a more fine-grained understanding of human resource information system which is the outcome of industry that act in the organizational level between the organizations (micro and macro level), thus, the phenomenon's complexity is difficult to grasp.

\subsection{Topics}

Our analysis shows a significant interest in studying the consequences of human resource information system in organizations, e.g adoption of the human resource information systems into organizational performance and other areas of function of human resources (Alam, Masum, Beh, \& Hong, 2016),(Gitari Muriithi Ag, Gachunga, \& Kathoka Mburugu, 2014), (Ahmer, 2013),(Chakraborty, Naha, \& Mansor, 2013),(Ngoc Duc, Siengthai, \& Page, 2013), (Fawzi Hasan Altaany, 2014),(Dmour, Love, \& Debei, 2016),(Rahman Khan, Hasan, \& Rubel, 2015), (AinhoaSaitua-Iribara, LoreaAndicoechea-Arondob, \& EnekaAlbizu-Gallastegic, 2014), (Ahmer, 2013), (Shahibi, Saidin, Adil, \& Izhar, 2016),(Mohan Thite, Don Kerr, 2007),(Thompson S.H. Teo, 2007).

There are also papers that examined the human resource information systems into decision making (Aliya Parvin, 2015),(Jadhav., 2016),(Lee, Lee, \& Kwon, 2005),(Beckers \& Bsat, 2002),(Bondarouk, Harms, \& Lepak, 2015), in design of human resource information system (Sajjad, 2014), (Teo, Lim, Fedric, \& Teo, 2007), (Carol Yeg Yun Lin, 1997), (Nishad Nawaz, 2014). The measuring of effectiveness of human resource information system (Majid Ramezan, 2010), (Caro et al., 2015), (Peres Adhiambo Opiyo \& Alice Abok, 2015), (Jyoti 
Sanjay Yadav, 2015),(Nishad Nawaz, 2014),(Shibly, 2011),(DeSanctis, 1986), (Marler \& Parry, 2016),(Haines \& Petit, 1997), (Eddy, Stone, \& Stone-Romero, 1999), employee participation into human resource information system (Urvashi Makkar, 2014),(Islam Faisal Bourini, 2011), (Ramesh kumar, Babartasneem shaikh, Jamil ahmed, Zulfiqar khan, \& Sayed mursalin, 2011a), (Nyeko \& Angundaru, 2017), (Mohammed owaisqureshi \& Syed rumaiya sajjad, 2013), (Devadesh Sharma, 2013), (Nishad Nawaz and Anjali, 2014), (Al-Balqa', 2016),(Beulen, 2008), (Al-Azzam, 2015a), (Razali \& Vrontis, 2010), (Leda \& Maria, 2005), (Weeks, 2013), (Davarpanah \& Mohamed, 2013), (Dmour et al., 2016),(Kristine Dery,David Grant, 2013), (Arthur \& Arthur, 2013), in the matter of health services human resource information contribution, (Tursunbayeva, Bunduchi, Pagliari, \& Franco, 2016), (Spero, McQuide, \& Matte, 2011), (Ramesh kumar, Babartasneem shaikh, Jamil ahmed, Zulfiqar khan, \& Sayed mursalin, 2011b), (Mofijul Islam Bulbul, Kalam Azad, Kanti Sarkar, Hakim, \& Haque, 2015), (Stefan Strohmeier and Rüdiger Kabst, 2007), (Tursunbayeva, Bunduchi, Franco, \& Pagliari, 2016b), (Tursunbayeva, Bunduchi, Franco, \& Pagliari, 2016a), (Juliadriessen, Dykkisettle, Davidpotenziani, \& Katetulenko, 2011), (Waters et al., 2013), (Dery, Hall, Wailes, \& Wiblen, 2013), (Lokhandwala, 2007), (Riley et al., 2011), (Al-Azzam, 2015a), (Roepke, Agarwal, \& Ferratt, 2000), (Tursunbayeva, Bunduchi, Franco, et al., 2016b).

Another topic that can be determined is the study of human resource information system in the context of impact on organization, (Bhuiyan, Rahman, \& Gani, 2015), (Saleem, 2012), (Mahmoud Al - Shawabkeh, 2014), (Khoualdi \& Basahel, 2014), (Nishad Nawaz, 2012c), (Tansley \& Watson, 2000), (Abdulrahman Al Shikhy, Zafir Mohd Makhbul, 2016), (Hani Al - Dmour et al., 2015), (Ferdous, Chowdhury, \& Bhuiyan, 2015), (Beadles Ii, Lowery, \& Johns, 2005), (Marouf \& Ur Rehman, 2005), (Richard Niehaus, 1996), in the area of implementation of human resource information system, (Aizhan Tursunbayeva, Claudia Palgliari, Raluca Bunduchi, 2016), (A. K. Singh, 2013), (Selvam Jesiah, 2012), (Habibullah Khan Syed Karamatullah Hussainy Kamran Khan Abdullah Khan, 2017), (Zykov, 2000), (Krishnan \& Singh, 2006), (Johnson, Lukaszewski, \& Stone, 2016), (Mohapatra, 2009), (Sharma \& Nathawat, 2014), (Bondarouk \& Ruel, 2008), (Mayfield, Mayfield, \& Lunce, 2003), (Bondarouk \& Looise, 2005), human resource information system influence on organization, (Neela Bhargava, Pradeep N E, 2012), (Anubhuti Monga, Dheeraj Chopra, Anubhav Monga, Monga, 2014), (Aime Noutsa, Robert Kala Kamdjoug, \& Fosso Wamba, 2017a), (Yousef Obeidat, 1941), (Al-Dmour \& Al-Zu'bi, 2014), (Dery, Grant, \& Wiblen, 2009), (Arthur \& Arthur, 1994), (Aime Noutsa, Robert Kala Kamdjoug, \& Fosso Wamba, 2017b).

Two articles can be assigned to the issues of human resource information systems, (Methuku \& Ramadan, 2013) and (Joan C. Hubbard, Karen A. Forcht, 1998). Eight papers have been discovered related to the process enhancement through human resource information system, (A. Singh, Shukla, \& Dwivedi, 2010), (Johnson et al., 2016), (Karikari, Boateng, \& Ocansey, 2015), (Nishad Nawaz, 2013b), (Raymond McLeod, 1995), (Ismail Al-Alawi, Al-Kandari, Hassan Abdel-Razek, \& Hassan Abdel, 2016), (S. K. Ball, 2012), (Liff, 1997), eight articles explain about the quality of work enhancement by using human resource information 
system,(Halima Begum, Faruk Bhuyian, A. S. A. Ferdous Alam, 2016), (Al-Azzam, 2015b), (Al-Rabei, Taber, Alaryan, \& Haija, 2015), (Tansley \& Watson, 2000), (Shahibi, Saidin, Adil, Izhar, et al., 2016), (Johnson, Burleson, \& Thatcher, 2012), (Ruel, Magalhaes, \& Charles, 2011), and (Jon Chao Hong, 1994), eight papers deep thought of theoretical development in aspect of human resource information system, (Nishad Nawaz Maditheti, 2017), (Mahmoud Moussa, 2014), (Daniel \& Kelly, 2001), (Nishad Nawaz and Anjali, 2012), (Nishad Nawaz, 2013a), (A. B. Raiden, Dainty, \& Neale, 2001), (Ngai \& Wat, 2006), and (Lippert, 2005).

Eleven articles can be determined in the study of human resource information systems role in organization,(Preet, Assistant, Jindal, \& Samim, 2011), (Gizela S tangl , Agnes Slavic Nemanja Berber, 2016), (Hoell, Hoell, \& Greenhalgh, 2012), (Preet et al., 2011), (Karikari et al., 2015), (Carole Tansley \& Sue Newell, 2007), (Joan C. Hubbard \& Thomas, 1998), (Maguire \& Redman, 2007), (Ordóñez De Pablos, 1994), (Lengnick-Hall \& Lengnick-Hall, 2006), and(Buckley, Minette, Joy, \& Michaels, 2004), five papers concentrated on higher education of human resource information system, (Altarawneh \& Al-Shqairat, 2010), (Davarpanah \& Mohamed, 2013), (Sharma \& Nathawat, 2014), (Nisha Bamel, 2014), and (Mohd Fuad Salleh, 2017), eighteen articles can be assigned to the study of human resource information system in general and covered human resource information usage in human resource management area, (Mohammed Owais Qureshi \& Syed Rumaiya Sajjad, 2013), (Garg., 2013), (Pivac, Tadić, \& Marasović, 2014), (Bhuiyan \& Osman Gani, 2015), (Maskuri \& Zin, 1999), (Zafar, 2013), (Nishad Nawaz, 2012b), (Germeier, Frese, \& Bücken, 2003), (A. Raiden, Williams, \& Dainty, 2008), (Hrdevadeshsharma \& Nathawat, 2014), (Hussain, Wallace, \& Cornelius, 2007), (Gerardine DeSanctis, 1986), (Gascó, Llopis, \& Reyes González, 2004), (Ken Gregson, 1996), (Bondarouk \& Looise, 2005), (Townsend \& Bennett, 2003), (Maier, Laumer, Eckhardt, \& Weitzel, 2013), and (Broderick \& Boudreau, 1991).

\section{Proposition of conceptual framework for the study of human resource information systems}

In the following, we propose a framework that highlights some conceptual domains that can be used to organize human resource information system research (figure 1). These domains were derived from the topics identified in our research review and represented in higher-order terms.

In the following, the domains are explained in brief.

- Interaction refers to interaction between individual / groups / Organizations and other individual / groups / Organizations as well as between these domains of HRM. The focus is on interactions between people.

- The qualities of the systems (i.e System Quality, Information Quality \& Service Quality) refer to the quality interaction.

- The interactions provide strategic process through effectiveness with security assurance to get smooth decision-making process by having legal \& ethical awareness. 


\section{Macrothink}

Journal of Management Research

ISSN 1941-899X

2017, Vol. 9, No. 3

- Attitude \& behavioral change to use refer to the employees getting into motivated to make use of human resource information system.

- Contributions to the end-user refer to that finally employee will get contribution by using human resource information system.

Even though the analysis of the papers left the expression that the domains have predominantly been studied in isolation to expand the body of information of human resource information system, future research should also look at the intersections of the different conceptual domains, as illustrated in Figure 1.

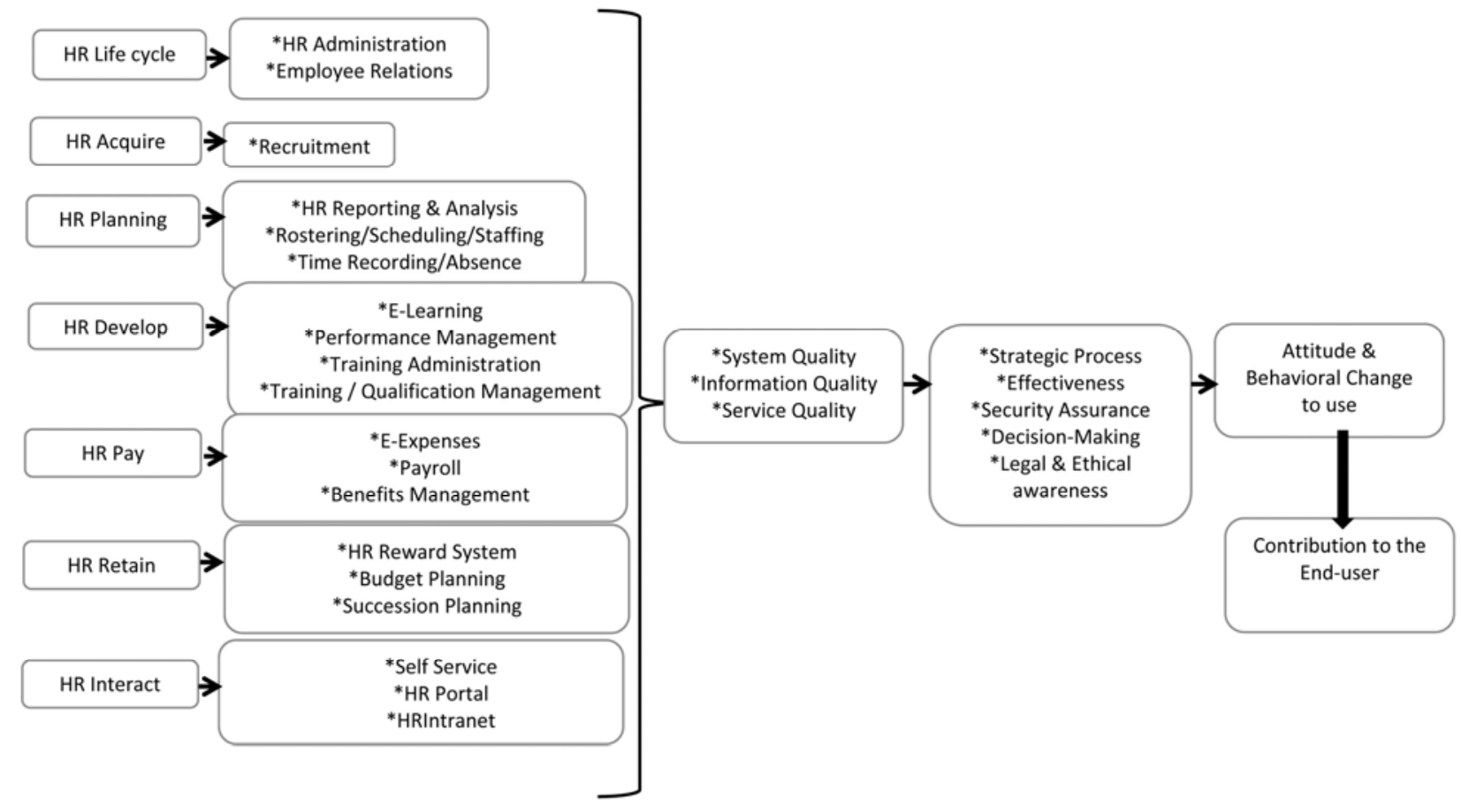

Figure 1. Human Resource Information Contribution Process

\section{Promising future research avenues}

The intent of this section is to provide concrete "food for thought" for researchers who are interested in conducting research in the area of human resource information system. The ideas are derived from the framework outlined above and the other findings presented previously. We commence with the proposition of some research ideas of the other aspects before we turn ideas that were derived from the conceptual framework.

\subsection{Research methodologies and methods}

The findings have shown that there is a critical need to take a more rigor research approach when addressing the topic. At the outset, the researchers should provide the necessary transparency regarding the research methodology and conceptual methodology chosen to demonstrate a rigor and comprehensible research approach and process. We convinced that the study of human resource information system would contribute from application of 
different world views. With regards to the possible research instruments, researchers may think of using different forms of data collection to get reliable information. Additionally, the future research should also design that follow the Actor Network Approach \& step-by-step approach. This would help the vendor to design new version of applications of human resource information system.

\subsection{Disciplines}

Researchers may also consider bringing additional disciplines to the study of human resource information system or bringing together different disciplines, e.g E HRM/ Wireless HRIS/ Mobile based Apps. This would help to develop a more holistic understanding, i.e more insights into the different facets of the topic; even though the inclusion of additional sub domains/ disciplines can increase the risk of fragmentation of the topic.

\subsection{Level of analysis}

This is another point we would like to draw the attention to. As outlined above, with many articles, it was very difficult, to make out the level of analysis. This again underline the need for better thought out and documented research approaches. As mentioned above, the addressing of the individual level of analysis and multiple level of analysis would be promising approaches to a deeper understanding of the topic. One challenge will be to design best navigation and user friendly applications, as this require well-trained researchers.

\subsection{Research avenues derived from conceptual framework}

Given the possible positive \& negative consequences of human resource information system, the advancement of the field would benefit from studies that look into the measurements and assessment of activities related to human resource information system in general and to specific activities such as information processing/ sharing. This research would help to better understanding the impact of human resource information system activities on firms/corporate success or failure and thus contribute to a stronger legitimation of those activities. Based on that more specific human resource information system updates strategies will be possible as well.

The present study of human resource information system at the strategic and operative level would be beneficial as well. For example, at the strategic level, it would be interesting to know what kind of information is to be considered as suitable for sharing which is not among the decision makers. At the operational level, it would be interesting to learn what is to be done to either share or protect different kinds of information/data. Thus, the focus would be on the information flow and the data in internal domains interaction of each other.

The intersections between individual/groups/organizations and organizational structure may also provide critical insights into the subject and their dealing with human resource information system. Given fact that the individuals can be assigned to different forms of organizational structure e.g functional domains structure, security, networks managing of all these are very difficult task, which may call for alternative forms of integrated governance on the organizational structure and HRIS environment. 
Finally, the interactions of the different domains call for the quality in system, information and service to get into the strategic process, effective employee communications which helps to make good decisions. Human resource information system will develop security assurance for the employees it will lead to the change of attitude in micro level and macro level they will come to know the legal \& ethical awareness. It will help employees to contribute to the organization to reach to the next level in the competitive environment.

\section{Conclusion}

The starting point of the paper was to establish the existing body of knowledge regarding human resource information system. Indeed, one can argue that without understanding of human resource information system and its possible consequences for organizations it will not be possible to developed new design of human resource information system. Consequently, this paper reviewed extant research on human resource information system. We used the method of a systematic literature review to do so.

Based on a final number of 155 articles, we determined the current body of knowledge regarding human resource information system. This contributes to a more holistic view of the topic and complements the study of human resource information system in general. Based on the systematic review, we have developed a framework that highlights conceptual domains of human resource information system that can help in organizing the study of information system based human resource services and in informing future research. This framework can be considered as the main contribution of this paper. Additionally, we have highlighted a number of other areas that are regarded as worth to be addressed to further our understanding of human resource information system.

Our results have implications for both theory and practice. From a theoretical point of view, this paper is positioned as a contribution to a more holistic study of human resource information system and practical point of view, the findings not only highlight possible consequences of doing nothing with regard to human resource information system, they also offer insights into how to cope with the challenge of human resource information system. Indeed, the study wants to underline that forward looking organizations take a strategic approach to human resource information system and have human resource information system information flow in place that enable them to better manage and distribute their quality information to the decision makers.

In conclusion, the authors of the present paper are convinced that the study of human resource information system is fruitful step for advancement of human resource information system and its practices. Having such an advanced understanding will also make it possible to develop human resource information system apps more comprehensible.

The authors are aware that the present study is not without limitations. Because of the chosen research procedure, this study may not have enabled complete coverage of all the articles in the field of human resource information system. Yet, it seems reasonable to assume that the review process covered a large share of published studies available. Finally, this paper proposes some future research directions, which are not exhaustive but represent initial 
stages.

\section{References}

Abdulrahman Al Shikhy, Zafir Mohd Makhbul, K. A. M. A. \& A. A. mazari. (2016). Modeling the impact of resistance to change within the context of human resources information systems adoption. Asian Academy of Management. The 11th AAM International Conference, 1(1), 1-10.

Ahmer, Z. (2013). Adotion of human resource information system innovation in Pakistani Organizations. Journal of Quality and Technology Management, IX(II), 25-50.

Aime Noutsa, F., Robert Kala Kamdjoug, J., \& Fosso Wamba, S. (2017a). Acceptance and Use of HRIS and Influence on Organizational Performance of SMEs in a Developing Economy: The Case of Cameroon. Springer International Publishing, 564-580. https://doi.org/10.1007/978-3-319-56535-4_57

Aime Noutsa, F., Robert Kala Kamdjoug, J., \& Fosso Wamba, S. (2017b). Acceptance and Use of HRIS and Influence on Organizational Performance of SMEs in a Developing Economy: The Case of Cameroon. Recent Advances in Information Systems and Technologies, Advances in Intelligent Systems and Computing, 563-580. https://doi.org/10.1007/978-3-319-56535-4_57

AinhoaSaitua-Iribara, LoreaAndicoechea-Arondob, \& EnekaAlbizu-Gallastegic. (2014). Humanresources information in the Management Report of the top Spanish companies. Procedia - Social and Behavioral Sciences, 109, 171-177.

https://doi.org/10.1016/j.sbspro.2013.12.439

Aizhan Tursunbayeva, Claudia Palgliari, Raluca Bunduchi, M. F. (2016). What does it take to implement Human Resource Information System (HRIS ) at scale? Analysis of the Expected Benefits and Actual Outcomes. 31st Workshop on Strategic Human Resource Management, $1-20$.

Al-Azzam, Z. F. (2015a). The Effect of Information System â€TM s on Quality Performance of Human Resource Management Functions through Using Human Resource Information Systems in Banking Industry of Jordan. International Journal Of Advanced Research in Engineering \& Management, 1(9), 38-59. https://doi.org/10.2139/ssrn.2710578

Al-Azzam, Z. F. (2015b). The Effect of Information System â€TM s on Quality Performance of Human Resource Management Functions through Using Human Resource Information Systems in Banking Industry of Jordan. International Journal Of Advanced Research in Engineering \& Management (IJAREM), 1(9), 38-59.

Al-Balqa', H. H. A. (2016). The impact of human resources information systems on the employee ${ }^{e c}$ performance. The International Conference on Business Organizations: Opportunities, Challenges, and Horizons, 1-17.

Al-Dmour, R. H., \& Al-Zu'bi, Z. M. F. (2014). Factors Motivating and Inhibiting the Practice of HRIS in Business Organizations: An Empirical Analysis. International Business Research, 
7(7), 139-155. https://doi.org/10.5539/ibr.v7n7p139

Al-Rabei, A. M., Taber, T. A. A., Alaryan, L. A., \& Haija, A. A. A. (2015). The Role of Accounting Information Systems in enhancing Human Resources Management Cycle in Jordanian Islamic Banks an Empirical Study. Australian Journal of Basic and Applied Sciences Aust. J. Basic \& Appl. Sci, 9(920), 437-441. Retrieved from www.ajbasweb.com

Alam, M. G. R., Masum, A. K. M., Beh, L. S., \& Hong, C. S. (2016). Critical factors influencing decision to adopt human resource information system (HRIS) in hospitals. PLoS ONE, 11(8), 1-22. https://doi.org/10.1371/journal.pone.0160366

Aliya Parvin. (2015). Human resource information systems of Jute Research Institute. International Journal of Information Technology and Business Management, 331(1), 33-40. Retrieved from www.jitbm.com

Altarawneh, I., \& Al-Shqairat, Z. (2010). Human Resource Information Systems in Jordanian Universities. International Journal of Business and Management, 5(10), 113-127. https://doi.org/10.5539/ijbm.v5n10p113

Anubhuti Monga, Dheeraj Chopra, Anubhav Monga, Monga. (2014). Understanding Human Resource Information System (HRIS) in Retrospect: An Analysis. International Journal of Engineering, Business and Enterprise Applications, 15(1), 77-80. Retrieved from http://iasir.net/IJSWSpapers/IJSWS14-349.pdf

Arthur, J. B., \& Arthur, J. B. (1994). Effects of Human Resource Systems on Manufacturing Performance and Turnover. The Academy of Management Journal, 37(3), 670-687. Retrieved from http://www.jstor.org/stable/256705

Arthur, J. B., \& Arthur, J. B. (2013). Effects of Human Resource Systems on Manufacturing Performance and Turnover. The Academy of Management Journal, 37(3), 670-687. Retrieved from http://www.jstor.org/stable/256705

Awazu, Y., \& Desouza, K. C. (2003). Knowledge management. Human Resource Magazine, 48(11), 107.

Ball, K. S. (2001). The use of human resource information systems: a survey. Personnel Review, 30(6), 677-693. https://doi.org/10.1108/EUM0000000005979

Ball, S. K. (2012). The use of human resource information systems: a survey. Personnel Review Kinnie and Arthurs, 30(6), 677-693.

Barnes, S. J. (2005). Assessing the value of IS journals. Communications of the ACM, 48(1), 110. https://doi.org/10.1145/1039539.1039573

Beadles, N., Lowery, C. M., Johns, K., Aston, N., \& Ii, B. (2005). An exploratory study on the public sector the impact of human resource information systems: An exploratory study in the public sector. Communications of the IIMA, 5(4), 39-46.

Beadles Ii, N. A., Lowery, C. M., \& Johns, K. (2005). The Impact of Human Resource Information Systems: An Exploratory Study in the Public Sector. An Exploratory Study on the 
Public Sector, 5(4), 39-46. https://doi.org/10.1016/j.jsis.2014.01.002

Beckers, A. M., \& Bsat, M. Z. (2002). A Dss Classification Model for Research in Human Resource Information Systems. Information Systems Management, 19(3), 1-10. https://doi.org/10.1201/1078/43201.19.3.20020601/37169.6

Benjamin, Alan, \& Benson, N. (1986). Why ignore the value of the people? Accountancy, 11(10), 81-84.

Beulen, E. (2008). Tthe contribution of a global service providers human resource information system to staff retention in emerging markets - Comparing and implemencations in six developing countries. Information Technology \& People, 1-25.

Bhuiyan, F., \& Osman Gani, M. (2015). Usage of Human Resource Information System and Its Application in Business: A Study on Banking Industry in Bangladesh. iBusiness, 7, 111-122. https://doi.org/10.4236/ib.2015.73013

Bhuiyan, F., Rahman, M. M., \& Gani, M. O. (2015). Impact of Human Resource Information Systems on Firms Financial Performance. International Journal of Business and Management, 10(10), 171-185. https://doi.org/10.5539/ijbm.v10n10p171

Bondarouk, T., Harms, R., \& Lepak, D. (2015). Does e-HRM lead to better HRM service? The International Journal of Human Resource Management, 1-31. https://doi.org/10.1080/09585192.2015.1118139

Bondarouk, T., \& Looise, J. K. (2005). HR Contribution to IT Innovation Implementation: Results of Three Case Studies. Creativity and Innovation Management, 14(2), 160-168.

Bondarouk, T. V., \& Ruel, H. J. M. (2008). HRM systems for successful information technology implementation: evidence from three case studies. European Management Journal, 26(3), 153-165. https://doi.org/10.1016/j.emj.2008.02.001

Brien, O. (2008). Introduction to information systems, (12 the ed.),. Tata McGraw-Hill, 242-243.

Broderick, R., \& Boudreau, J. W. (1991). The evolution of computer use in human resource management: Interviews with ten leaders. Human Resource Management, 30(4), 485-508. https://doi.org/10.1002/hrm.3930300405

Bryman, A. (2012). Social research methods, 4th Edition. Oxford University Press.

Buckley, P., Minette, K., Joy, D., \& Michaels, J. (2004). The use of an automated employment recruiting and screening system for temporary professional employees: A case study. Human Resource Management. https://doi.org/10.1002/hrm.20017

Caro, J. D., Lagman, A. G., Feria, R. P., Solamo, R. C., Betan, A. S., Noel, P., \& Paje, G. (2015). Multi - Campus Implementation of University Information Systems. Philippine Computing Journal, 1-8.

Carol Yeg Yun Lin. (1997). Human Resource Information Systems: Implementation in 
Taiwan. Research \& Pracice in Human Resource Management, 5(1), 57-72.

Carole Tansley \& Sue Newell. (2007). A Knowledge-based View of Agenda-formation in the Development of Human Resource Information Systems. Management Learning, 38(1), 95-119.

Chakraborty, A. R., Naha, N., \& Mansor, A. (2013). Adoption of Human Resource Information System: A Theoretical Analysis. Physics Procedia, 75, 473-478. https://doi.org/10.1016/j.sbspro.2013.04.051

Chris Hart. (1998). Doing a Literature Review Releasing the social science research imagination. SAGE Publications.

Daniel, M., \& Kelly, M. (2001). Towards a human resource information system for Australian construction companies. Engineering Construction and Architectural Management, 8(4), 238-249. Retrieved from http://eprints.qut.edu.au/archive/00004127

Davarpanah, A., \& Mohamed, N. (2013). Human Resource Information Systems ( HRIS ) Success Factors In A Public Higher Education Institution Context. 3rd International Conference on Research and Innovation in Information Systems - 2013 (ICRIIS'13), 3, 79-84. https://doi.org/10.1109/ICRIIS.2013.6716689

Davison, R., De Vreede, G. J., Briggs, R. O., Davison, R., Jan De Vreede, G., \& Briggs, R. O. (2005). On Peer Review Standards for the Information Systems Literature. Communications of the Association for Information Systems, 16, 967-980.

Dery, K., Grant, D., \& Wiblen, S. (2009). Human Resource Information Systems (HRIS ): Replacing or Enhancing HRM. Work and Organisational Studies: The University of Sydney ., 1-10. $\quad$ Retrieved from https:/www.researchgate.net/profile/David_Grant8/publication/228793352_HUMAN_RESO URCE_INFORMATION_SYSTEMS_(HRIS)_REPLACING_OR_ENHANCING_HRM/link s/00b4951b9857b720f4000000.pdf

Dery, K., Hall, R., Wailes, N., \& Wiblen, S. (2013). Lost in translation? An actor-network approach to HRIS implementation. Journal of Strategic Information Systems, 22(3), 225-237. https://doi.org/10.1016/j.jsis.2013.03.002

DeSanctis, G. (1986). Human Resource Information Systems: A Current Assessment. MIS Quarterly, 10(1), 14. https://doi.org/10.2307/248875

Dessler Gary, Cole Nina D., \& S. V. L. (2008). Human Resources Management In Canada. Prentice-Hall Canada Inc. Scarborough, Ontario.

Devadesh Sharma. (2013). Resistance to Human Resource Information Systems (HRIS) Problem Recognition, Diagnosis and Positive Intervention: A Study on Employee Behavior and Change Management. Indian Journal of A, 3(1), 99-104. https://doi.org/10.15373/2249555X/JAN2013/39

Dmour, R. H. Al, Love, S., \& Debei, M. M. Al. (2016). Factors influencing the organisational 
adoption of human resource information systems: a conceptual model. International Journal of Business Innovation and Research, 11(2), 1-4. https://doi.org/10.1504/IJBIR.2016.077986

Eddy, E. R., Stone, D. L., \& Stone-Romero, E. F. (1999). The effects of information management policies on reactions to human resource information systems: an integration of privacy and procedural justice perspectives. Personnel Psychology, 52(2), 335-358. https://doi.org/10.1111/j.1744-6570.1999.tb00164.x

Fawzi Hasan Altaany. (2014). Facilitation of Human Resource Information Systemson Performance of Public Sector in Jordan. Fawzi Hasan Altaany Int. Journal of Engineering Research and Applications, 4(2 v), 183-190. Retrieved from www.ijera.com

Ferdous, F., Chowdhury, M. M., \& Bhuiyan, F. (2015). Barriers to the Implementation of Human Resource Information Systems. Asian Journal of Management Sciences \& Education, 4(1), 33-42.

Fink, A. G. (2005). Conducting Research Literature Reviews. SAGE Publications, 3 rd Edition.

Fink, D. (1998). Guidelines for the Successful Adoption of Information Technology in Small and Medium Enterprises. International Journal of Information Management, 18(4), 243-253. https://doi.org/10.1016/S0268-4012(98)00013-9

Garg., P., \& N. (2013). A perceptual study of human resource information system in Indian organizations. Journal of Organisation \& Human Behaviour, 2(4), 21-27.

Gascó, J. L., Llopis, J., \& Reyes González, M. (2004). The use of information technology in training human resources. Journal of European Industrial Training, 28(5), 370-382. https://doi.org/10.1108/03090590410533062

Gerardine DeSanctis. (1986). Human Resource Information Systems: A Current Assessment. MIS Quarterly, 10(1), 15-27. Retrieved from http://www.jstor.org/stable/248875

Germeier, C. U., Frese, L., \& Bücken, S. (2003). Concepts and data models for treatment of duplicate groups and sharing of responsibilities in genetic resources information systems. Genetic Resources and Crop Evolution, 50(7), 693-705. https://doi.org/10.1023/A:1025030913231

Gitari Muriithi Ag, J., Gachunga, H., \& Kathoka Mburugu, C. (2014). Effects of Human Resource Information Systems on Human Resource Management Practices and Firm Performance in Listed Commercial Banks at Nairobi Securities Exchange. European Journal of Business and Management Online, 6(29), 2222-2839.

Gizela S tangl, Agnes Slavic Nemanja Berber, \& B. L. (2016). The Role of Human Resource Management in Small and Medium Sized Companies in Central-Eastern Europe. Economic Development and Entrepreneurship in Transition Economies, 205-229.

Gueutal, H.G., \& Stone, D. L. (2005). The Brave New World of eHR: Human Resources Management in the Digital Age. Jossey-Bass, San Francisco, CA. 
Habibullah Khan Syed Karamatullah Hussainy Kamran Khan Abdullah Khan. (2017). The Applications, Advantages and Challenges in the implementation of HRIS in Pakistani perspective Abstract. Journal of Information and Knowledge Management Systems, 47(1), 1-19.

Haines, V. Y., \& Petit, A. (1997). Conditions for successful human resource information systems. Human Resource Management, 36(2), 261-275. https://doi.org/10.1002/(SICI)1099-050X(199722)36:2<261::AID-HRM7>3.0.CO;2-V

Halima Begum, Faruk Bhuyian, A. S. A. Ferdous Alam, \& A. H. A. (2016). Productivity Improvement and HR Costs Reduction Through HRIS: A Survey On Banking Industry In Bangladesh. International Symposium on Sustainable Development and Management, 101-110.

Hani Al - Dmour, R., Professor, A., Aldmour, R., edu jo Bader Yousef Obeidat, J., Professor, A., Moh, E., \& Abdelkarim Almajali, D. (2015). The Practice of HRIS Applications in Business Organizations in Jordan: An Empirical Study. Conference Proceedings(COES\&RJ-CP), 2(5), 53-74.

Hendrickson, A. R. (2003). Human resource information systems: Backbone technology of contemporary human resources. Journal of Labor Research, 24(3), 381-394. https://doi.org/10.1007/s12122-003-1002-5

Hoell, R. C., Hoell, J. F., \& Greenhalgh, S. M. (2012). An analysis of human resource information systems courses in accredited schools of business Alyssa Oravec. Int. J. Information and Operations Management Education, 5(1), 7-23. https://doi.org/10.1504/IJIOME.2012.051589

Hrdevadeshsharma, \& Nathawat, S. S. (2014). Resistancein Learning Hrisin Education Andit Companies. International Journal of Scientific Research, 3(11), 282-286.

Hussain, Z., Wallace, J., \& Cornelius, N. E. (2007). The use and impact of human resource information systems on human resource management professionals. Information \& Management, 44(1), 74-89. https://doi.org/10.1016/j.im.2006.10.006

Islam Faisal Bourini. (2011). Investigating the Relationship between Human Resource Information System and Strategic Capability among Employees : Jordan Case Study. Journal of Advanced Social Research, 1, 63-75.

Ismail Al-Alawi, A., Al-Kandari, S. M., Hassan Abdel-Razek, R., \& Hassan Abdel, R. (2016). Evaluation of Information Systems Security Awareness in Higher Education: An Empirical Study of Kuwait University. Journal of Innovation Journal of Innovation \& Business Best Practice, 2016(2016), 1-24. https://doi.org/10.5171/2016.329374

Jadhav., K. R. and A. (2016). Intelligent Decision Support Systems - A Tool for Human Resource Allocation in Information Technology Projects. International Journal of Computer Science and Information Technologies, 7(5), 2356-2364.

Joan C. Hubbard, Karen A. Forcht, D. S. T. (1998). Human Resource Information Systems: 
An Overview of Current Ethical and Legal Issues Joan. Journal of Business Ethics, 17, 1319-1323.

Joan C. Hubbard, K. A. F., \& Thomas, D. S. (1998). Human Resource Information Systems: An Overview of Current Ethical and Legal Issues Joan. Journal of Business Ethics, 17, 1319-1323.

Johnson, R. D., Burleson, J., \& Thatcher, J. B. (2012). Moving beyond automation: A frameowk and research agenda studying the role of information systems in E-HR. Proceedings of the Southern Association for Information Systems Conference, 124-130.

Johnson, R. D., Lukaszewski, K. M., \& Stone, D. L. (2016). The evolution of the field of human resource information systems: Co-Evolution of technology and HR processes. Communications of the Association for Information Systems, 38(1), 533-553.

Jon Chao Hong. (1994). The Process of Successful Technology Transfer. Industrial and Commercial Training, 26(11), 17-21.

Juliadriessen, Dykkisettle, Davidpotenziani, \& Katetulenko, T. (2011). Understanding and valuing the broader health system benefits of Uganda's national Human Resources for Health Information System investment. Human Resources for Health, 13(49), 1-9. https://doi.org/10.1186/s12960-015-0036-0

Jyoti Sanjay Yadav. (2015). Study of human resource information system in industrial area of Sangli city. Indian Journal of Applied Research, 4(2), 1-19.

Kapoor, S. (2012). Human resource information system in New World. Prime Management Journal, 4(2), 123-134.

Karikari, A. F., Boateng, P. A., \& Ocansey, E. O. N. D. (2015). The Role of Human Resource Information System in the Process of Manpower Activities. American Journal of Industrial and Business Management, 5(5), 424-431. https://doi.org/10.4236/ajibm.2015.56042

Ken Gregson. (1996). Information resource management. Work Study, 44(1), 20-21.

Khoualdi, K., \& Basahel, A. (2014). The Impact of Implementing SAP System on Human Resource Management: Application to Saudi Electricity Company. International Journal of Business and Management, 9(12), 28-34. https://doi.org/10.5539/ijbm.v9n12p28

Krishnan, S. K., \& Singh, M. (2006). Issues and Concerns in the Implementation and Maintenance of HRIS. Indian Institute of Management Research and Publications, 1, 1-16. https://doi.org/10.1007/s13398-014-0173-7.2

Kristine Dery,David Grant, N. W. \& S. W. (2013). Putting the HR into the HRIS: A study of the implementation of Human Resource Information Systems Abstract. Academy of Management Annual Meeting Proceeding; 1-33.

Leda, P., \& Maria, V. (2005). E-HR adoption and the role of HRM : Evience from Greece. SSRN Electronic Journal, 1-30. Retrieved from http://ssrn.com/abstract=975442 
Lee, C.-S., Lee, C. C., \& Kwon, H.-B. (2005). A Framework of Outsourcing Decision-Making for Human Resource Information Systems. HR Focus, 82, 1-6. Retrieved from http://eplu.plu.edu

Lengnick-Hall, C. A., \& Lengnick-Hall, M. L. (2006). HR, ERP, and knowledge for competitive advantage. Human Resource Management. https://doi.org/10.1002/hrm.20103

Levy, Y., \& Ellis, T. J. (2006). A systems approach to conduct an effective literature review in support of information systems research. Informing Science, 9, 181-211. https://doi.org/10.1049/cp.2009.0961

Liff, S. (1997). Constructing HR information systems. Human Resource Management Journal, 7(2), 18-31. https://doi.org/10.1111/j.1748-8583.1997.tb00279.x

Lippert, S. K. \& P. M. S. (2005). Human resource information systems (HRIS) and technology trust Susan. Journal of Information Science, 31(5), 2005.

Lokhandwala, S. (2007). IT is from Mars, HR is from Venus. The National Journal of Human Resource Management, 1-2.

Maguire, S., \& Redman, T. (2007). The role of human resource management in information systems development. Management Decision, 45(2), 252-264. https://doi.org/10.1108/00251740710727278

Mahmoud Al - Shawabkeh, K. (2014). Human Resource Information Systems and Their Impact on Human Resource Management Strategies : A Field Study in Jordanian Commercial Banks. Journal of Management Research, 6(4), 99-108. https://doi.org/10.5296/jmr.v6i4.5660

Mahmoud Moussa. (2014). A Review of Human Resource Information Systems (HRISs) in Organizations. SIU Journal of Management, 4(1), 149-181.

Maier, C., Laumer, S., Eckhardt, A., \& Weitzel, T. (2013). Analyzing the impact of HRIS implementations on HR personnel's job satisfaction and turnover intention. Journal of Strategic Information Systems, 1-15. https://doi.org/10.1016/j.jsis.2012.09.001

Majid Ramezan. (2010). Measuring the effectiveness of human information systems in national Iranian oil comapny (an empirical assessment). Education Business and Society Contemporary Middle Eastern Issues, 1-18.

Marler, J. H., \& Parry, E. (2016). Human resource management, strategic involvement and e-HRM technology. The International Journal of Human Resource Management, 1-22. https://doi.org/10.1080/09585192.2015.1091980

Marouf, L., \& Ur Rehman, S. (2005). Organizational and human resource aspects of IT management A case study of Kuwaiti corporate companies. The Electronic Library, 23(4), 383-397. https://doi.org/10.1108/02640470510611454

Maskuri, R., \& Zin, A. (1999). Using formal specification to validate a human resource information system. Malaysian Journal of Computer Science, 12(2), 1-9. 
Mayfield, M., Mayfield, J., \& Lunce, S. (2003). Human resource information systems: A review and model development. Advances in Competitiveness Research, 11(1), 139-151.

Mayfield M., \& Mayfield J., L. S. (2003). Human resource information systems: a review and model development. Advances in Competitiveness Research, 11, 139-151.

McCrindle, M. (2006). New Generations at Work: Attracting, Recruiting, Retraining \& Training Generation Y. McCrindle Research, Sydney.

McNulty, T., Zattoni, A., \& Douglas, T. (2013). Developing Corporate Governance Research through Qualitative Methods: A Review of Previous Studies. Corporate Governance: An International Review, 21(2), 183-198. https://doi.org/10.1111/corg.12006

Methuku, H., \& Ramadan, H. (2013). A Study on Developing the Role of Human Resource Information Systems for Good Leadership. American Journal of Industrial and Business Management, 3, 497-506. https://doi.org/10.4236/ajibm.2013.35057

Mofijul Islam Bulbul, M., Kalam Azad, A., Kanti Sarkar, S., Hakim, L., \& Haque, E. (2015). Development of HRIS (Human Resource Information System) for Health: Enormous impact to Strengthen Health System in Bangladesh. International Scientific Conference of Public Health Foundation of Bangladesh, 1-2.

Mohammed Owais Qureshi, \& Syed Rumaiya Sajjad. (2013). A Comparative Study of the Software Packages Used as HRIS by Organizations Operating in India: Human Resource Professionals Perspective. European Journal of Business and Management, 5(16), 2222-2839.

Mohammed Owaisqureshi, \& Syed Rumaiya Sajjad. (2013). An empirical analysis of organizations using human resource information system(HRIS) in India: An employee perspective, 2(9), 54-63.

Mohan Thite, \& Don Kerr, K. S. (2007). Problems and prospects in teaching multidisciplinary courses: a case study of human resource information systems. International Journal of Information and Operations Management Education, 2(2), 183-193.

Mohapatra, S. (2009). Framework for HRIS Implementation in Non-IT Sector. Journal of Convergence Information Technology, 4(4), 111-117. https://doi.org/10.4156/jcit.vol4.issue4.16

Mohd Fuad Salleh. (2017). Organizational Learning as Moderating Variable Between Human Resource Information System and Public Universities' Performance. Chinese Business Review, 1-15.

Neela Bhargava, Pradeep N E, S. K. (2012). Technological advancements and its influence on transformation of HRIS. Research Gate, (December), 0-7.

Ngai, E. W. T., \& Wat, F. K. T. (2006). Human resource information systems: a review and empirical analysis. Personnel Review, 35(3), 297-314. https://doi.org/10.1108/00483480610656702 
Ngoc Duc, N., Siengthai, S., \& Page, S. (2013). A conceptual model of HRIS-Trust: an understanding of suppliers'/customers' relationship. Foresight, 15(2), 106-116. https://doi.org/10.1108/14636681311321112

Nisha Bamel, U. K. B. and V. S. \& M. T. (2014). Usage, benefits and barriers of human resource information system in universities. Human Resource Information System, 44(4), 519-536.

Nishad Nawaz. (2012a). Time \& cost savings advantages with usage of human resource information system in select software companies in Bangalore City. Indian Journal of Applied Research, 1(12), 161-163.

Nishad Nawaz. (2012b). Time and cost savings advantages with usage of HRIS in select software companies in Bangalore City. Indian Journal of Applied Research, 1(12), 161-163.

Nishad Nawaz. (2012c). To assess the impact of human resource information system in facilitating information flow among the select software companies in Bangalore. India. Research Journal of Management Sciences, 1(3), 1-8.

Nishad Nawaz. (2013a). Human Resource Information Systems -A Review. International Journal of Management, IT and Engineering, 3(1), 74-98.

Nishad Nawaz. (2013b). The usage of human resource information systems in HR processes in select software companies in Bangalore City India. Information and Knowledge Management, 3(12), 102-112. Retrieved from www.iiste.org

Nishad Nawaz. (2014). Human resource information system as a tool for effective decision making in select software companies in Bangalore, Karnataka, India. International Journal of Business and Management Review, 2(1), 90-107.

Nishad Nawaz and Anjali. (2012). Automation of the HR functions enhance the professional efficiency of the HR professionals-A Review. International Journal of Management, IT and Engineering, 2(6), 402-416.

Nishad Nawaz and Anjali. (2014). To assess the level of employee satisfaction on HRIS usage in select software companies in Bangalore, Karnataka, India. Elixir - Human Resource Management, 66, 20438-20441.

Nishad Nawaz Maditheti. (2017). A Comprehensive Literature Review of the Digital HR Research Filed. Information and Knowledge Management, 7(4), 15-20. Retrieved from www.iiste.org

Nyeko, J. S., \& Angundaru, G. (2017). Employee Adoption and Use of Human Resource Information Systems (HRIS ): Evidence from Ugandan Local Government Perspective. International Journal of Scientific Research in Science and Technology, 3(1), 327-340.

Ordóñez De Pablos, P. (1994). Human resource management systems and their role in the development of strategic resources: empirical evidence. Journal of European Industrial Training, 28(6), 474-489. https://doi.org/10.1108/03090590410542701 
Ostermann, H., Staudinger, B.,\& Staudinger, R. (2009). Benchmarking human resource information systems. In T. Coronas \& M. Oliva (Ed.), Encyclopedia of Human Resources Information Systems: Challenges in E-HRM. Hershey, PA. IGI Global.

Peres Adhiambo Opiyo \& Alice Abok. (2015). Effect of human resource information system on performance of commercial banks in Kenya : A case of Kenya Commercial Bank. Journal of Business Management, 1(1), 1-29.

Petticrew, M., \& Roberts, H. (2006). Systematic Reviews in the Social Sciences: A Practical Guide. Blackwell. https://doi.org/10.1027/1016-9040.11.3.244

Pivac, S., Tadić, I., \& Marasović, B. (2014). The level of the usage of the human resource information system and electronic recruitment in Croatian companies. Croatian Operational Research Review, 291(5), 291-304. https://doi.org/10.17535/crorr.2014.0014

Preet, H., Assistant, S., Jindal, S., \& Samim, S. A. (2011). Role of Human Resource Information System in Banking Industry of Developing Countries. The First International Conference on Interdisciplinary Research and Development, 19(SPI), 44.1-44.4.

Rahman Khan, A., Hasan, N., \& Rubel, M. (2015). Factors Affecting Organizations Adopting Human Resource Information Systems : A Study in Bangladesh. IOSR Journal of Business and Management Ver. II, 17(11), 2319-7668. https://doi.org/10.9790/487X-171124554

Raiden, A. B., Dainty, A. R. J., \& Neale, R. H. (2001). Hman resource information system in construction: Are their capabilities fully exploited? Association of Researchers in Construction Management, 1, 133-142.

Raiden, A., Williams, H., \& Dainty, A. (2008). Human resource information systems in construction - A review seven years on. Human Resource Information Systems, 93-102.

Ramesh kumar, Babartasneem shaikh, Jamil ahmed, Zulfiqar khan, \& Sayed mursalin. (2011a). The human resource information system : a rapid appraisal of Pakistan 's capacity to employ the tool. BMC Medical Informatics and Decision Making, 13(104), 1-6. https://doi.org/10.1186/1472-6947-13-104

Ramesh kumar, Babartasneem shaikh, Jamil ahmed, Zulfiqar khan, \& Sayed mursalin. (2011b). The human resource information system: a rapid appraisal of Pakistan's capacity to employ the tool. BMC Medical Informatics \& Decision Making, 13(104), 1-6. https://doi.org/10.1186/2046-1682-4-13

Raymond McLeod, J. \& G. D. (1995). A Resource Flow Model of the Human Resource Information System. Journal of Information Technology Management, VI(3), 1-15.

Razali, Z., \& Vrontis, D. (2010). The Reactions of Employees Toward the Implementation of Human Resources Information Systems (HRIS) as a Planned Change Program: A Case Study in Malaysia. Journal of Transnational Management, 15, 229-245. https://doi.org/10.1080/15475778.2010.504497

Richard Niehaus. (1996). Information technology and HR. Human Resource Planning, 19(1), 
$56-61$.

Riley, P. L., Zuber, A., Vindigni, S. M., Gupta, N., Verani, A. R., Sunderland, N. L., ... Campbell, J. (2011). Information systems on human resources for health : a global review. Human Resources for Health, 10(7), 1-12. https://doi.org/10.1186/1478-4491-10-7

Roepke, R., Agarwal, R., \& Ferratt, T. W. (2000). Aligning the IT Human Resource with Business Vision: The Leadership Initiative at 3M. MIS Quarterly, 24(2), 327. https://doi.org/10.2307/3250941

Rousseau, D., Manning, J., \& Denyer, D. (2008). Evidence in Management and Organizational Science: Assembling the Field's Full Weight of Scientific Knowledge Through Syntheses. SSRN eLibrary, 67(8), 1-78. https://doi.org/10.1080/19416520802211651

Ruel, H., Magalhaes, R., \& Charles. (2011). Human Resource Information System: An Integrated Research Agenda. Electronic HRM in Theory and Practice (Vol. 8). https://doi.org/doi:10.1108/S1877-6361(2011)0000008006

Sajjad, M. O. Q., \& R. (2014). Human Resource Information System-A boon or bane for the human resource professionals in India. International Research Journal of Management Sociology \& Humanity Page, 5(3), 379-383. Retrieved from www.irjmsh.com

Saleem, I. (2012). Impact of adopting HRIS on three tries of HRM Evidence from Developing Economy. Business Review, 7(2), 96-105.

Schuler R.S., Jackson S.E., S. J. J. (2001). HRM and its link with strategic management, in: J. Storey (Ed.), Human Resource Management: A Critical Text, second ed.,. Thomson Learning, London,.

Selvam Jesiah. (2012). Implementation Issues of Aadhaar: Human Resource Information System for India. Springer, India, 763-789.

Sethi, V., \& King, W. R. (1998). Organizational Transformation Through Business Process Reengineering: Applying the Lessons Learned. Upper Saddle River, NJ: Prentice Hall. Retrieved from https://books.google.com.sg/books/about/Organizational_Transformation_Through_Bu.html? id=a_bkAAAAMAAJ\&pgis $=1$

Shahibi, M. S., Saidin, A., Adil, T., \& Izhar, T. (2016). Evaluating User Satisfaction on Human Resource Management Information System (HRMIS): A Case of Kuala Lumpur City Hall, Malaysia. International Journal of Academic Research in Business and Social Sciences, 6(10), 95-116. https://doi.org/10.6007/IJARBSS

Shahibi, M. S., Saidin, A., Adil, T., Izhar, T., Selangor, U., \& Alam, S. (2016). A Framework Based on Human Resource Management Information System ( HRMIS ) for the Evaluation of Users Satisfaction. International Journal of Academic Research in Business and Social Sciences, 6(10), 2222-6990. https://doi.org/10.6007/IJARBSS/v6-i10/2333

Sharma, D., \& Nathawat, S. S. (2014). Education And It Companies in Relation To Happiness 
And Satisfaction in Human Resource Information Systems). Global Journal for Research Analysis, 3(10), 76-81.

Shibly, H. Al. (2011). Human Resources Information Systems success Assessment: An integrative model. Australian Journal of Basic and Applied Sciences, 5(5), 157-169.

Singh, A. K. (2013). The Contemporary HRIS. Global Journal of Finance \& Management, 5(4), 68-72.

Singh, A., Shukla, T., \& Dwivedi, N. (2010). Recruitment cycle time cycle analysis for human resource information system. Innovations and Advances in Computer Science and Engineering, 377-384.

Spero, J. C., McQuide, P. A., \& Matte, R. (2011). Tracking and monitoring the health workforce: a new human resources information system (HRIS) in Uganda. Human Resources for Health, 9(1), 6. https://doi.org/10.1186/1478-4491-9-6

Stefan Strohmeier, \& Rüdiger Kabst. (2007). Do Current HRIS Meet the Requirements of HRM?: An Empirical Evaluation using Logistic Regression and Neural Network Analysis. In Proceedings of the 1st International Workshop on Human Resource Information Systems (pp. 1-14). https://doi.org/10.5220/0002418500310044

Tansley, C., \& Watson, T. (2000). Strategic exchange in the development of Human Resource Information Systems (HRIS). New Technology Work Employment, 15(2), 108-122. https://doi.org/10.1111/1468-005X.00068

Teo, T. S. H., Lim, G. S., Fedric, S. A., \& Teo, S. H. (2007). The adoption and diffusion of human resources information systems in Singapore. Asia Pacific Journal of Human Resources, 45(1), 44-62. https://doi.org/10.1177/1038411107075402

Tetz, F. (1974). System for managing human resources. Journal of Systems Management, $10-14$.

Thompson S.H. Teo, G. S. L. and S. A. F. (2007). The adoption and diffusion of human resources information systems in Singapore. Asia Pacific Journal of Human Resources, 45(1), 2007.

Townsend, A. M., \& Bennett, J. T. (2003). Human Resources and Information Technology. Journal of Labour Research, XXIV(3), 361-363.

Tursunbayeva, A., Bunduchi, R., Franco, M., \& Pagliari, C. (2016a). Human resource information systems in health care: a systematic evidence review. Journal of the American Medical Informatics Association Advance, 1, 1-22. https://doi.org/10.1093/jamia/ocw141

Tursunbayeva, A., Bunduchi, R., Franco, M., \& Pagliari, C. (2016b). Human resource information systems in health care: a systematic evidence review. Journal of the American Medical Informatics Association, 24(3), 633-654. https://doi.org/10.1093/jamia/ocw141

Tursunbayeva, A., Bunduchi, R., Pagliari, C., \& Franco, M. (2016). Thinking big whilst making do: Mismatching expectations of a national human resource information system in 
healthcare. European Group for Organizational Studies, 1-30.

Ulrich D. (1997). Human Resource Champions: The Next Agenda for Adding Value to HR Practices. Harvard Business School Press, Boston, MA,.

Urvashi Makkar, R. S. (2014). Determining employees perception through effective HRIS : An empirical study. Journal of Strategic Human Resource Management, 3(3), 26-32. https://doi.org/10.2139/ssrn.2762089

Waters, K. P., Zuber, A., Willy, R. M., Kiriinya, R. N., Waudo, A. N., Oluoch, T., ... Riley, P. L. (2013). Kenya's Health Workforce Information System: A model of impact on strategic human resources policy, planning and management. International Journal of Medical Informatics, 82(9), 895-902. https://doi.org/10.1016/j.ijmedinf.2013.06.004

Webster, J., \& Watson, R. T. (2002). Analyzing the past to prepare for the future: Writing a literature review Reproduced with permission of the copyright owner. Further reproduction prohibited without permission. MIS Quarterly, 26(2), 13-23. https://doi.org/10.2307/4132319

Weeks, K. O. (2013). An Analysis of Human Resource Information Systems impact on Employees. Journal of Management Policy \& Practice, 14(3), 35-50. Retrieved from http://search.ebscohost.com/login.aspx?direct=true\&profile=ehost\&scope=site \&authtype $=$ cra wler\&jrnl=19138067\&AN=94484543\&h=jcLFMXG9oZGucKiNRaE/7jSv7CpPytfZP9CZn Bt5dCqCtQWIbIVc06VKbL95RXAIB8UKqTVyTtlKD+vPXS4r3A==\&crl=c

Yousef Obeidat, B. (1941). The Relationship between Human Resource Information System (HRIS) Functions and Human Resource Management (HRM) Functionalities. Journal of Management Research, 4(4), 192-211. https://doi.org/10.5296/jmr.v4i4.2262

Zafar, H. (2013). Human resource information systems: Information security concerns for organizations. Human Resource Management Review, 23(1), 105-113. https://doi.org/10.1016/j.hrmr.2012.06.010.

Zykov, S. V. (2000). Towards Implementing an Enterprise Groupware-Integrated Human Resources Information System. Proceedings of the 2nd International Workshop on Computer Science and Information Technologies, 1-9. 